\title{
Faktor Risiko Kejadian Anemia pada Ibu Hamil di Rumah Sakit BARI Palembang
}

\author{
Siti Amallia ${ }^{1}$, Rahmalia Afriyani ${ }^{2}$, Siska Putri Utami ${ }^{3}$ \\ ${ }^{1,2,3}$ Program Studi Kebidanan, STIK Siti Khadijah Palembang \\ Email: azesilia.89@gmail.com
}

\begin{abstract}
Risk Factor on the Appearance of Anemia on Maternity Women In BARI Hospital Palembang. The appearance of anemia during the maternity caused the death of mothers indirectly. Based on the data from BARI Hospital Palembang in 2015, it was found for about 29 (13\%) of 2218 maternity mothers affected by anemia. The objectives of this study were to discover the influential factors on the appearance of anemia on maternity women in the BARI Hospital Palembang in 2015. The cross-sectional approach was applied in this study. The population of the study was all the maternity women who checked their pregnancy in the BARI Hospital in 2015. There were 236 respondents taken by using simple random sampling. Data were analyzed by using frequency analysis, chi-square analysis, and logistic regression analysis. The result of study showed that $31(13.1 \%)$ respondents got anemia during their pregnancy, there was the correlation between the age $(p$-value $=0.032)$ and parity of maternity women $(p$-value $=0.005)$ on anemia, and there was no correlation between the education and occupation of maternity women who affected by anemia. The regression logistic test showed that age and parity influenced the affection of anemia on maternity women and the most influential factor was the parity with $\mathrm{OR}=4.012$. Suggested to health officer will improve the counseling for maternity women about the importance of family planning after childbirth and control the number of children, so anemia cases in pregnancy will be decreased.
\end{abstract}

Keywords: Anemia, Age, Parity, Education, Occupation

\begin{abstract}
Abstrak: Faktor Risiko Kejadian Anemia pada Ibu Hamil di Rumah Sakit BARI Palembang. Anemia pada kehamilan dapat menyebabkan kematian secara tidak langsung. Data yang di dapat dari Rumah Sakit BARI Palembang tahun 2015 sebanyak 29 (1,3\%) ibu yang mengalami anemia dari 2218 orang ibu hamil. Tujuan penelitian untuk mengetahui faktor yang mempengaruhi kejadian anemia pada ibu hamil di Rumah Sakit BARI Palembang tahun 2015. Penelitian ini menggunakan metode analitik dengan pendekatan cross sectional. Populasi dalam penelitian ini adalah seluruh ibu hamil yang memeriksakan kehamilannya di Rumah Sakit BARI Palembang tahun 2015. Sampel dalam penelitian ini menggunakan teknik random sampling, dengan jumlah sampel 236 responden. Data dianalisis dengan mengunakan uji frequensi, uji chi square dan uji regresi logistic. Hasil penelitian menunjukan bahwa 31 $(13,1 \%)$ responden mengalami kejadian anemia pada kehamilan. Selanjutnya terdapat hubungan antara usia dan paritas ibu hamil dengan kejadian anemia dengan nilai usia ( $\rho$ value $=0,032)$, paritas $(\rho$-value $=0,005)$ dan tidak terdapat hubungan antara tingkat pendidikan dan pekerjaan dengan kejadian anemia pada ibu hamil. Uji regresi logistic menunjukan bahwa faktor usia dan paritas mempengaruhi kejadian anemia pada ibu hamil dan faktor paritas merupakan faktor yang paling dominan dengan $\mathrm{OR}=4,012$. Petugas kesehatan diharapkan untuk lebih meningkatkan kegiatan penyuluhan kepada ibu hamil tentang pentingnya melakukan KB setelah persalinan dan membatasi jumlah anak, sehingga kejadian anemia dalam kehamilan dapat menurun.
\end{abstract}

Kata kunci: Anemia, Usia, Paritas, Pendidikan, Pekerjaan

Banyak faktor yang dapat mempengaruhi kematian ibu salah satunya disebabkan karena anemia dalam kehamilan. Anemia merupakan suatu keadaan adanya penurunan kadar hemoglobin, hematokrit dan jumlah eritrosit dibawah nilai normal. Pada penderita anemia, lebih sering disebut kurang darah, kadar sel darah merah $(\mathrm{Hb})$ dibawah nilai normal. Penyebabnya adalah kurangnya zat besi untuk pembentukan darah, misalnya zat besi, asam folat, dan vitamin B12. Tetapi yang sering terjadi adalah anemia karena kekurangan zat besi (Rukiyah, 2010).

Status zat besi tiap individu bermacammacam mulai dari excess zat besi sampai anemia defisiensi zat besi. Walaupun kebutuhan zat besi bervariasi pada tiap grup yang tergantung pada 
faktor-faktor seperti pertumbuhan (bayi, remaja, kehamilan) dan perbedaan kehilangan normal zat besi (menstruasi dan kelahiran), terjadi proses yang diatur tubuh dalam meningkatkan absorpsi zat besi sejalan dengan penggunaan zat besi dan menurunkan absorpsi zat besi yang disimpan di dalam tubuh sejalan dengan adanya asupan makanan (Gleason \& Scrimshaw dalam Arumsari, 2008).

Zat besi pada masa kehamilan digunakan untuk perkembangan janin, plasenta, ekspansi sel darah merah, dan untuk kebutuhan basal tubuh. Zat besi yang diperlukan dapat diperoleh dari makanan dan tablet besi. Akan tetapi, seperti halnya konsumsi zat gizi secara umum, konsumsi zat besi seringkali belum memenuhi kebutuhan dalam tubuh (Darlina, 2003). Apabila kadar zat besi di dalam tubuh ibu hamil kurang, maka akan terjadi suatu keadaan yang disebut anemia. Hal itu dikarenakan zat besi merupakan mikroelemen ang esensial bagi tubuh. Zat ini terutama diperlukan dalam hemopoiesis (pembentukan darah), yaitu dalam sintesa hemoglobin. Sebagaimana telah diketahui bahwa rendahnya kadar hemoglobin dalam darah mengakibatkan suatu keadaan yang disebut anemia (Sediaoetama 1987, dalam Tristiyanti 2006).

Di Indonesia pada tahun 2010 angka kejadian anemia masih cukup tinggi yaitu 50-70 juta jiwa, anemia defisiensi besi (anemia yang disebabkan kurang zat besi) mencapai 20\%-33\%. Sedangkan $40,1 \%$ anemia dialami wanita hamil dengan batas bawah $11 \mathrm{gr} / \mathrm{dl}$ (Lestari, 2010).

Anemia dalam kehamilan adalah kondisi ibu dengan kadar hemoglobin kurang dari 10,0 gram/100 milimeter (10gram/desiliter) (Varney, 2006). Sebagian besar wanita hamil mengalami anemia yang tidak membahayakan. Tetapi anemia akibat kelainan bawaan pada hemoglobin bisa mempersulit kehamilan. Kelainan tersebut meningkatkan risiko penyakit dan kematian pada bayi baru lahir dan meningkatkan penyakit pada ibu (Maulana, 2008).

Adapun faktor-faktor dapat mempengaruhi kejadian anemia pada ibu hamil yaitu faktor dasar (sosial ekonomi, pengetahuan, pendidikan, dan budaya), faktor tidak langsung (Kunjungan Antenatal Care, paritas, umur, dan dukungan suami), faktor tidak langsung (pola konsumsi tablet $\mathrm{Fe}$, penyakit infeksi, dan perdarahan) (Wiknjosastro, 2007).

Menurut data dari dinas kesehatan di Provinsi Sumatera Selatan, anemia pada ibu hamil tahun 2012 terdapat $692(1,51 \%)$ orang dari 45.652 ibu hamil, pada tahun 2013 terdapat ibu hamil dengan anemia sebanyak $646(1,77 \%)$ orang dari 36.487 ibu hamil, sedangkan pada tahun 2014 terdapat ibu hamil dengan anemia $675(1,4 \%)$ orang dari 48.235 ibu hamil (Dinkes Provinsi Sumatera Selatan, 2014).

Di kota Palembang pada tahun 2012 terdapat ibu hamil sebanyak 31.502, dengan angka kejadian anemia sebanyak $1.017(3,10 \%)$ ibu hamil, pada tahun 2013 ibu hamil sebanyak 32.302 dengan angka kejadian anemia sebanyak 1.001 (3,0\%), pada tahun 2014 terdapat 33.309 ibu hamil dengan kejadian anemia sebanyak $1.028(3,0 \%)$ orang (Dinkes kota Palembang, 2014).

Menurut data dari Rumah Sakit BARI Palembang pada tahun 2012 jumlah ibu hamil sebanyak 1.817 orang dan tidak terdapat kejadian anemia pada ibu hamil, tahun 2013 jumlah ibu hamil sebanyak 1.954 orang dan ibu hamil yang mengalami kejadian anemia sebanyak 8 orang (0,4\%), sedangkan pada tahun 2014 jumlah ibu hamil sebanyak 2.218 orang dan ibu hamil yang mengalami anemia sebanyak 29 orang (1,3\%), dari data diatas menunjukan bahwa terjadi kenaikan angka kejadian anemia pada ibu hamil di Rumah Sakit BARI Palembang (RS. BARI Palembang, 2014).

Rasmaliah (dalam Tristiyanti, 2006) menyebutkan bahwa anemia merupakan penyebab penting yang melatarbelakangi kejadian morbiditas dan mortalitas, yaitu kematian ibu pada waktu hamil dan pada waktu melahirkan atau nifas sebagai akibat komplikasi kehamilan. Selain itu ibu hamil yang menderita anemia juga menunjukkan keadaan yang tragis, yaitu terjadinya perdarahan pada saat melahirkan. Di samping pengaruhnya kepada kematian dan perdarahan, anemia pada saat hamil akan mempengaruhi pertumbuhan janin, berat bayi lahir rendah dan peningkatan kematian perinatal. Mengetahui hal tersebut maka perlu dilakukan penelitian untuk mengetahui faktor yang mempengaruhi kejadian anemia pada ibu hamil di Rumah Sakit BARI Palembang tahun 2015.

\section{METODE}

Jenis penelitian ini menggunakan metode kuantitatif yang bersifat survey analitik dengan pendekatan cross sectional. Populasi dalam penelitian ini adalah seluruh ibu hamil yang memeriksakan kehamilanya di Rumah Sakit BARI Palembang. Sampel penelitian berjumlah 236 responden diambil menggunakan teknik random sampling dan dilakukan dengan cara undian atau lotere. Penelitian dilakukan pada tanggal 18-30 Januari 2016. Teknik pengumpulan data diambil dari data sekunder 
didapatkan dari rekam medik di Rumah Sakit BARI Palembang tahun 2015. Data dianalisis dengan mengunakan uji frequensi untuk analisis univariat, Chi-Square $\left(\mathrm{X}^{2}\right)$ untuk analisis bivariat dan regresi logistic untuk analisis multivariat.

\section{HASIL}

\section{A. ANALISIS UNIVARIAT}

Tabel 1. Distribusi Frekuensi Responden

\begin{tabular}{lrr}
\hline \multicolumn{1}{c}{ Variabel } & Jumlah & \% \\
\hline Usia & & \\
Risiko Tinggi & 85 & 36,0 \\
Risiko Rendah & 151 & 64,0 \\
Paritas & & \\
Risiko Tinggi & 131 & 55,5 \\
Risiko Rendah & 105 & 44,5 \\
Pendidikan & & \\
Tinggi & 79 & 33,5 \\
Rendah & 157 & 66,5 \\
Pekerjaan & & \\
Ya & 145 & 61,4 \\
Tidak & 91 & 38,6 \\
Anemia & & \\
Ya & 31 & 13,1 \\
Tidak & 205 & 86,9 \\
\hline
\end{tabular}

Distribusi frekuensi variabel penelitian terlihat pada tabel 1 menunjukkan bahwa dari 236 orang responden distribusi frekuensi usia ibu tertinggi dalam kategori risiko rendah sebesar $151(64,0 \%)$, distribusi frekuensi paritas ibu tertinggi dalam kategori risiko tinggi sebesar 131 $(55,5 \%)$, distribusi frekuensi pendidikan ibu tertinggi dalam kategori rendah sebesar 157 $(66,5 \%)$, distribusi frekuensi pekerjaan ibu tertinggi dalam kategori bekerja sebesar 145 $(61,4 \%)$, dan distribusi frekuensi kejadian anemia pada ibu hamil tertinggi dalam kategori tidak anemia sebesar 205 (86,9\%).

\section{B. ANALISIS BIVARIAT}

Analisis bivariat menunjukkan terdapat hubungan yang signifikan antara usia dan paritas dan tidak ada hubungan yang signifikan antara pendidikan dan pekerjaan dengan kejadian anemia pada ibu hamil di Rumah Sakit BARI Palembang diperoleh melalui analisis Chi-square terlihat pada Tabel.2.
Tabel 2. Faktor yang Berhubungan dengan Kejadian Anemia pada Ibu Hamil di Rumah Sakit BARI Palembang

\begin{tabular}{lccc}
\hline $\begin{array}{l}\text { Variabel } \\
\text { penelitian }\end{array}$ & p value & OR & $\begin{array}{c}\text { Confidence } \\
\text { Interval }\end{array}$ \\
\hline Usia & $0,032^{*}$ & 2,446 & $1,139-5,256^{* *}$ \\
Paritas & $0,005^{*}$ & 3,892 & $1,532-9,885^{* *}$ \\
Pendidikan & $0,092^{*}$ & 2,065 & $0,962-4,433^{* *}$ \\
Pekerjaan & $0,829^{*}$ & 1,176 & $0,546-2,532^{* *}$ \\
\hline${ }^{*} \alpha=0,005$ & $* * 95 \%$ confidance interval
\end{tabular}

Hasil uji statistik Chi-Square pada tabel 2 didapatkan variabel usia menunjukkan $p$-value $(0,032)<\alpha(0,05)$ yang berarti ada hubungan yang signifikan antara Usia dengan kejadian anemia pada ibu hamil, variabel paritas menunjukkan $p$-value $(0,005)<\alpha(0,05)$ yang berarti ada hubungan yang signifikan antara paritas dengan kejadian anemia pada ibu hamil, variabel pendidikan menunjukkan p-value $(0,092)>\alpha(0,05)$ yang berarti tidak ada hubungan yang signifikan antara pendidikan dengan kejadian anemia pada ibu hamil, dan variabel pekerjaan menunjukkan $p$-value $(0,829)$ $>\alpha(0,05)$ yang berarti tidak ada hubungan yang signifikan antara pendidikan dengan kejadian anemia pada ibu hamil.

\section{ANALISIS MULTIVARIAT}

Analisis multivariat dilakukan untuk mengetahui pengaruh tiap-tiap variabel bebas secara bersama-sama terhadap variabel terikat. Variabel yang dianalisis secara regresi adalah variabel bebas yang secara bivariat mempunyai hubungan dengan nilai $p \leq 0.25$. Hasil pemodelan regresi yang baik ditujukan untuk mendeskripsikan variabel-variabel yang berpengaruh terhadap kejadian anemia pada ibu hamil. Uji yang digunakan dalam analisis multivariat adalah regresi logistic nominal dengan metode Backward LR Berikut ini adalah model akhir hasil analisis regresi logistik.

Tabel 3. Model Akhir Hasil Analisis Regresi Logistik

\begin{tabular}{lccc}
\hline Variabel & B & Sig. & OR \\
\hline Usia & 0,899 & 0,026 & 2,457 \\
Paritas & 1,389 & 0,004 & 4,012 \\
Pendidikan & 0,790 & 0,052 & 2,203 \\
Constant & 0,458 & 0,241 & \\
\hline
\end{tabular}

Selanjutnya dihitung persamaan regresi untuk mengetahui besarnya probabilitas terjadinya variabel dependen. Diketahui pada tabel 3. diatas nilai $\alpha=0,458$ dan dari variabel usia ibu nilai $\beta=0,899$, Paritas $\beta=1,389$, dan pendidikan nilai $\beta=0,790$ serta nilai konstanta 
2,7. Nilai-nilai tersebut dimasukkan kedalam persamaan regresi sebagai berikut:

$$
r(x)=1 /\left(1+e^{-y}\right)
$$

$$
\begin{aligned}
\mathrm{y}= & 0,458+0,889(\mathrm{usia} \mathrm{ibu})+ \\
& 1,389(\text { paritas })+0,790(\text { pendidikan })
\end{aligned}
$$

Dengan asumsi bahwa $\pi(\mathrm{x})$ adalah probabilitas kejadian anemia pada ibu hamil. Setelah nilai-nilai tersebut diatas dimasukkan dalam persamaan model, diperoleh hasil sebesar 0.97 (97\%). Hasil ini menunjukkan bahwa apabila ketiga variabel secara bersama-sama dalam kategori usia risiko tinggi, paritas risiko tinggi, dan ibu dengan pendidikan tinggi, maka probabilitas kejadian anemia pada ibu hamil adalah sebesar $97 \%$.

\section{PEMBAHASAN}

\section{Faktor yang Berhubungan dengan Kejadian Anemia pada Ibu Hamil di Rumah Sakit BARI}

Berdasarkan hasil uji statistik Chi-Square didapatkan $p$-value $(0,032)<\alpha(0,05)$ yang berarti ada hubungan yang signifikan antara Usia dengan kejadian anemia pada ibu hamil di Rumah Sakit BARI Palembang. Diperoleh pula nilai $\mathrm{OR}=2,446$ artinya responden yang usia risiko tinggi mempunyai kecenderungan 2,446 kali lebih besar mengalami anemia dibandingkan responden yang usia risiko rendah. Hal ini disebabkan karena kejadian anemia berkaitan dengan usia ibu yang tidak dalam masa reproduksi yang sehat dimana wanita yang melahirkan anak pada usia dibawah 20 tahun atau lebih dari 35 tahun merupakan faktor resiko terjadinya anemia pada kehamilan.

Hasil penelitian Noversiti (2012), yang melakukan penelitian di wilayah kerja Puskesmas Air Dingin Kota Padang tentang faktor-faktor yang hubungan dengan kejadian anemia pada ibu hamil trimester III. Dimana ibu hamil dengan usia risiko tinggi mengalami kejadian anemia sebanyak 56,8\% responden, sedangkan ibu hamil yang memiliki usia resiko rendah dengan kejadian anemia sebanyak $53,2 \%$ responden. Dari hasil uji statistik Chi-Square, didapatkan nilai $\rho$-value $s \alpha(0,05)$ yang berarti ada hubungan antara usia ibu hamil dengan kejadian anemia.

Amiruddin (2007), menyatakan kejadian anemia dapat berkaitan dengan alat-alat reproduksi wanita usia reproduksi sehat dan aman adalah usia 20-35 tahun. Kehamilan di usia
$<20$ tahun dan >35 tahun dapat menyebabkan kejadian patologi.

Selanjutnya pada Tabel 2, menjelaskan nilai $p$-value $=0,005$ untuk variabel paritas, yang berarti ada hubungan yang signifikan antara paritas dengan kejadian anemia pada ibu hamil di RSUD Bari Palembang. Diperoleh pula nilai $\mathrm{OR}=3,892$ artinya responden yang paritas tinggi mempunyai kecenderungan 3,892 kali lebih besar mengalami anemia dibandingkan responden yang paritas rendah. Hal ini dikarenakan pada setiap kehamilan dan persalinan akan terjadi perubahan serabut otot menjadi jaringan ikat pada uterus hal ini dapat menurunkan kemampuan uterus. Paritas 1 keadaan ibu lemah dan baru pertama mengalami kehamilan jadi banyak keadaan yang terjadi seperti lemah, kurang nafsu makan, dan khawatir dengan keadaan bayi sehingga kemungkinan dapat terjadinya anemia. Begitu sebaliknya paritas $\geq 3$ fungsi dari alat reproduksi ibu menurun sehingga keadaan ibu lemah, sehingga kejadian anemia menjadi besar.

Hasil penelitian Qudsiah (2013) yang melakukan penelitian di Puskesmas Bangerayu Kecamatan Genuk Kota Semarang tentang hubungan paritas ibu dengan kejadian anemia. Dimana usia responden secara keseluruhan menunjukkan bahwa sebagian besar responden memiliki paritas resiko tinggi dengan kejadian anemia sebanyak $57,9 \%$ responden sedangkan paritas resiko rendah dengan kejadian anemia sebanyak $42,1 \%$ dari 127 responden mendapatkan hasil $p$-value $\leq \alpha(0,05)$ berarti ada hubungan antara paritas dengan kejadian anemia.

Saifuddin (2007) mengungkapkan paritas 2-3 merupakan paritas paling aman ditinjau dari sudut kematian maternal. Pada paritas tinggi lebih dari 3 mempunyai angka kematian maternal lebih tinggi di bandingankan dengan paritas rendah.

Hasil uji statistik pada tabel 2, untuk tingkat pendidikan ibu dengan kejadian anemia didapatkan $p$-value $=0,092$ yang artinya $(p>\alpha=$ $0,05)$ hasil ini menunjukkan bahwa tidak terdapat hubungan antara tingkat pendidikan dengan kejadian anemia pada ibu hamil dan artinya tidak terdapat kecenderungan ibu dengan tingkat pendidikan tinggi untuk tidak menderita anemia ataupun sebaliknya. Sebagian besar responden yang memiliki tingkat pendidikan tinggi dapat menderita anemia pada kehamilan. Hal ini mungkin disebabkan oleh faktor lain yaitu perilaku ibu yang kurang memperhatikan kesehatan dan kurang mampu mengatasi masalah kesehatannya.

Hasil penelitian ini sejalan dengan penelitian yang dilakukan oleh Noversiti (2012) 
yang mejelaskan bahwa tidak terdapat hubungan yang signifikan antara tingkat pendidikan dengan kejadian anemia pada kehamilan $p$-value $=0,101$. Meskipun sebagian besar responden memiliki tingkat pendidikan yang tinggi, namun tidak semua responden yang memiliki pendidikan tinggi juga memiliki pengetahuan baik yang dapat mempengaruhi perilaku kesehatannya.

Hasil penelitian ini didukung oleh pendapat Herawati dan Astuti (2010) pendidikan merupakan salah satu faktor yang mempengaruhi terbentuknya perilaku seseorang. Perilaku dan tindakan yang dihasilkan oleh pendidikan di dasarkan pada pengetahuan dan kesadaran yang terbentuk melalui proses pembelajaran dan perilaku ini diharapkan akan berlangsung lama dan menetap karena didasari oleh kesadaran.

Berdasarkan tabel 2, hasil uji statistik untuk variabel pekerjaan didapatkan nilai $p$ value $=0,829$ yang artinya $(p>\alpha=0,05)$ Hasil penelitian ini menunjukan bahwa tidak terdapat hubungan yang signifikan antara pekerjaan dengan kejadian anemia, ibu hamil yang berkerja dan tidak berkerja memiliki kecenderungan yang hampir sama untuk menderita anemia pada kehamilan. Sebagian besar ibu yang berkerja tidak menderita anemia pada kehamilan.

Hasil penelitian ini sejalan dengan penelitian yang dilakukan oleh Fikriana (2013) yang menjelaskan bahwa tidak terdapat hubungan yang signifikan antara pekerjaan dan kejadian anemia pada ibu hamil dengan nilai $p=0,777$.

Hasil penelitian ini didukung pendapat yang dikemukaan oleh Purbadewi (2013) pekerjaan merupakan suatu aktifitas sehingga memperoleh penghasilan. Jenis pekerjaan menentukan pengahasilan yang di dapatkan. Ibu hamil yang berkeja mempunyai penghasilan untuk membatu suami dalam mencukupi kebutuhan sehari-hari. Ibu hamil yang memiliki penghasilan berhubungan dengan kemampuan ibu hamil untuk mendapatkan pengetahuan tentang anemia karena tercukupi keuangan keluarganya.

Hasil penelitian menunjukkan bahwa variabel paritas merupakan faktor yang paling dominan mempengaruhi kejadian anemia pada kehamilan. pada paritas 2-3 merupakan paritas paling aman ditinjau dari sudut kematian maternal. Pada paritas tinggi lebih dari 3 mempunyai angka kematian maternal lebih tinggi di bandingankan dengan paritas rendah (Saifuddin, 2007).

\section{Faktor yang Mempengaruhi Kejadian Anemia pada Ibu Hamil di Rumah Sakit BARI Palembang}

Hasil analisis multivariat dengan uji regresi logistik didapatkan dua variabel yang secara signifikan mempengaruhi kejadian anemia pada ibu hamil di Rumah Sakit BARI Palembang yaitu varibel usia dan paritas. Variabel paritas merupakan variabel yang paling dominan mempengaruhi kejadian anemia pada ibu hamil. Responden yang paritasnya tinggi lebih cenderung mengalami anemia dibandingkan dengan responden yang paritasnya rendah. Hal ini dikarenakan pada setiap kehamilan dan persalinan akan terjadi perubahan serabut otot menjadi jaringan ikat pada uterus hal ini dapat menurunkan kemampuan uterus.

Penelitian ini berbeda dari hasil penelitian Tristiyanti (2006), dimana usia kehamilan dan ANC (pemeriksaan kehamilan) yang berpengaruh nyata terhadap status anemia pada ibu hamil. Kedua variabel tersebut memberikan pengaruh terhadap status anemia pada ibu hamil sebesar $25,2 \%$.

Namun, penelitian ini sejalan dengan pendapat yang dikemukakan oleh Awalia, $d k k$ (2010) bahwa semakin sering seorang wanita mengalami kehamilan dan melahirkan akan semakin banyak kehilangan zat besi dan semakin menjadi anemia.

\section{SIMPULAN}

1. Dari 236 orang responden terdapat sebagian besar responden tidak mengalami kejadian anemia pada kehamilan $(86,9 \%)$, usia dengan kategori resiko rendah $(64,0 \%)$, paritas dengan kategori tinggi $(55,5 \%)$, pendidikan dengan kategori rendah $(66,5 \%)$, dan yang memiliki pekerjaan $(61,4 \%)$.

2. Terdapat hubungan yang signifikan antara usia (p-value $=0,032)$, dan paritas (pvalue $=0,005)$ dan tidak terdapat hubungan yang signifikan antara pendidikan (pvalue $=0,092)$, dan pekerjaan ibu (pvalue $=0,829)$ dengan kejadian anemia pada ibu hamil di Rumah Sakit BARI Palembang tahun 2015.

3. Usia, Paritas dan Pendidikan mempengaruhi kejadian anemia pada ibu hamil sebesar $97 \%$, dengan faktor yang dominan yaitu paritas $(\mathrm{OR}=4,012)$. 


\section{SARAN}

Disarankan kepada petugas kesehatan untuk memberikan penyuluhan yang mudah diterima oleh ibu hamil, seperti di bukanya kelas ibu hamil untuk diberikan informasi pentingnya pemberian zat besi dan mengkonsumsi makanan yang baik untuk ibu hamil, dan lebih

\section{DAFTAR PUSTAKA}

Amiruddin. 2007. Pengantar Metode Penelitian. Bandung: PT. Citra Aditya Bakti.

Arumsari, E. 2008. Faktor Risiko Anemia pada Remaja Putri Peserta Program Pencegahan dan Penanggulangan Anemia Gizi Besi (PPAGB) di Kota Bekasi. Skripsi, Program Studi Gizi Masyarakat Dan Sumberdaya Keluarga Fakultas Pertanian Institut Pertanian Bogor.

Awalia, dkk. 2010. Kejadian Anemia pada Ibu Hamil. Unit Penelitian dan Pengembangan Jurusan Kebidanan. Poltekkes Kemenkes Palembang.

Darlina. 2003. Faktor-faktor yang Berhubungan dengan Kejadian Anemia Gizi pada Ibu Hamil. Skripsi, Departemen Gizi Masyarakat dan Sumberdaya Keluarga, Fakultas Pertanian, Institut Pertanian Bogor.

Dinas Kesehatan Sumatera Selatan. 2014. Buku Profil Kesehatan Sumatera Selatan. Sumatera Selatan. Dinas Kesehatan Provinsi Sumatera Selatan.

Dinas Kesehatan Kota Palembang. 2014. Buku Profil Kesehatan Kota Palembang. Sumatera Selatan. Dinas Kesehatan Kota Palembang.

Fikriana, Umi. 2013. Faktor-faktor yang Mempengaruhi Kejadian Anemia pada Ibu Hamil di Puskesmas Kasihan II Bantul. Tesis. STIK Aisyah: Jogjakarta.

http://digilib.unisayogya.ac.id/2724/1/nask ah\%20publikasi_indah\%20fitriasari_1610 104376_8a_div\%20bidan\%20pendidik.pdf (Diakses pada 03 Januari 2016).

Herawati, Cucu, Sri Astuti. 2010. Faktor -faktor yang Berhubungan dengan Anemia Gizi pada Ibu Hamil di Puskesmas Jalaksana Kuningan Tahun 2010. Jurnal Kesehatan Kartika. http://www.stikesayani.ac.id/publikasi/ejournal/files/2010/201012/201012-007.pdf

Lestari, Sri. 2010. Hubungan antara Usia Ibu, Paritas, Pendidikan dan Pengetahuan dengan Kejadian Anemia di Rumah Sakit memperhatikan juga pada ibu yang paritas resiko tinggi untuk diawasi dalam mengkonsumsi tablet Fe sehari-hari dan mengkonsumsi makanan tinggi zat besi, serta memberi informasi tentang pentingnya melakukan KB setelah persalinan dan membatasi jumlah anak, sehingga kejadian anemia dalam kehamilan dapat menurun.

Bersalin Utami Kecamatan Batangan Kabupaten Pati. Tesis, Fakultas Kesehatan Masyarakat. Universitas Muhammdiyah Semarang.

http://digilib.unimus.ac.id/gdl.php?mod=br owse\&op=read\&id=jtptunimus-gdl-s1-

2008-srilestari-517 (Diakses 03 Januari 2016).

Maulana, M. 2008. Penyakit Kehamilan dan Pengobatannya. Jogyakarta.

Noversiti, Elsy. 2012. Faktor-faktor yang Berhubungan dengan Anemia pada Ibu Hamil Trimester III di Wilayah Kerja Puskesmas Air Dingin Kota Padang. Skripsi UNAND.

http://etd.repository.ugm.ac.id/downloadfil e/92052/potongan/D4-2016-321339-

BIBLIOGRAPHY.pdf (Diakses 19

Desember 2015).

Purbadewi, Lindungan, Ulfi Yuliana Noor Setiawati. 2013. Hubungan Tingkat Pengetahuan tentang Anemia dengan Kejadian Anemia pada Ibu Hamil. Jurnal Gizi Universtas Muhamdiyah Semarang. http://repository.uinjkt.ac.id/dspace/bitstre am/123456789/26380/1/maulida\%20Nur\% 20Soraya-fkik.pdf (Diakses pada 19 Desember 2015).

Qudsiah, Siti Chadlirotul, Herry Suswanti Djarot, Siti Nurjanah. 2013. Hubungan Antara Paritas dan Umur dengan Anemia pada ibu Hamil Trimester III. Jurnal Kebidanan Universitas Muhamdiyah Semarang, Volume 2, Nomor 3, 2013. http://jurnal.unimus.ac.id/index.php/jur_bi d/article/view/815 (Diakses 23 Desember 2015).

RSUD Palembang Bari 2014. Rekam Medik profil RSUD Palembang Bari. Sumatera Selatan.

Rukiyah, Ai Yeyeh. 2010. Asuhan Kebidanan Patologi Kebidanan 4. Jakarta Timur: CV. Trans Info Media.

Saifuddin. 2007. Ilmu Kebidanan dan Penyakit Kehamilan. Jakarta: EGC. 
Tristiyanti, W. F. 2006. Faktor-faktor yang Mempengaruhi Status Anemia pada Ibu Hamil di Kecamatan Ciampea, Kabupaten Bogor, Jawa Barat. Skripsi, Program Studi S1 Gizi Masyarakat dan Sumberdaya Keluarga Fakultas Pertanian Institut Pertanian Bogor.
Varney, H. 2006. Buku ajar Asuhan Kebidanan Edisi 4. Jakarta: EGC.

Wiknjosastro, Hanifa. 2007. Ilmu Kebidanan. Jakarta: Yayasan Bina Pustaka Sarwono Prawirohardjo. 